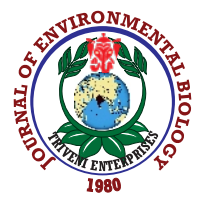

\title{
Assessment of sand dune ecosystems with Pancratium maritimum, Bartın, Turkey
}

\author{
Y. Sarı Nayim \\ Department of Landscape Architecture, Bartın University, Bartın, 74100, Turkey \\ *Corresponding Author Email : ynayim@bartin.edu.tr
}

\begin{abstract}
Aim: Dunes not only comprise one of the most beautiful natural attributes in the world but are also one of the most sensitive ecosystems. The objective of this study is to ensure that Pancratium maritimum $L$. that is facing threats of extinction and the Bartın dune biotopes are passed over to posterity with the protection activities that will be carried out at the local scale.
\end{abstract}

Methodology: In this study, the sea daffodils and Bartın dunes located on Kızılkum, Mugada, Güzelcehisar, İnkum and Göçgündemirci coastal ecosystems were examined under two headings, "the fragility of Bartın coastal dune ecosystems and Pancratium maritimum species" and "the impact of tourism activities and recreational uses in the Bartın dune ecosystems". Data acquired from literature reviews, floristic studies, site observations were evaluated on the basis of Integrated Coastal Zone Management (ICZM) Protocol and Ecosystem Approach (EsA). Vegetation/Floristic survey and vegetation map methods are generally preferred for the management of human effect in coastal recreation areas. Within this scope, field studies were carried out to record the floristic data and habitat information of the sea daffodil at the Bartın dune ecosystems, distribution of individuals were mapped, and rating was carried out according to their densities.

Results: The study showed that recreational tourism activities had a adverse effect on Pancratium maritimum and on its habitats. Furthermore, alternative active precautions, such as production trials, preparation of dune ecosystem maintenance and repair projects should be urgently taken.

Interpretation: Ensuring the conditions for growing dune species, taking necessary environmental protection precautions and making necessary environmentally-friendly arrangements is a must in such highly sensitive areas as Bartın sand dunes. It is only after then it will be possible to transfer significant dune species, as Pancratium maritimum along with their habitats.

Key words: Bartın, Sand dune ecosystems, Pancratium maritimum
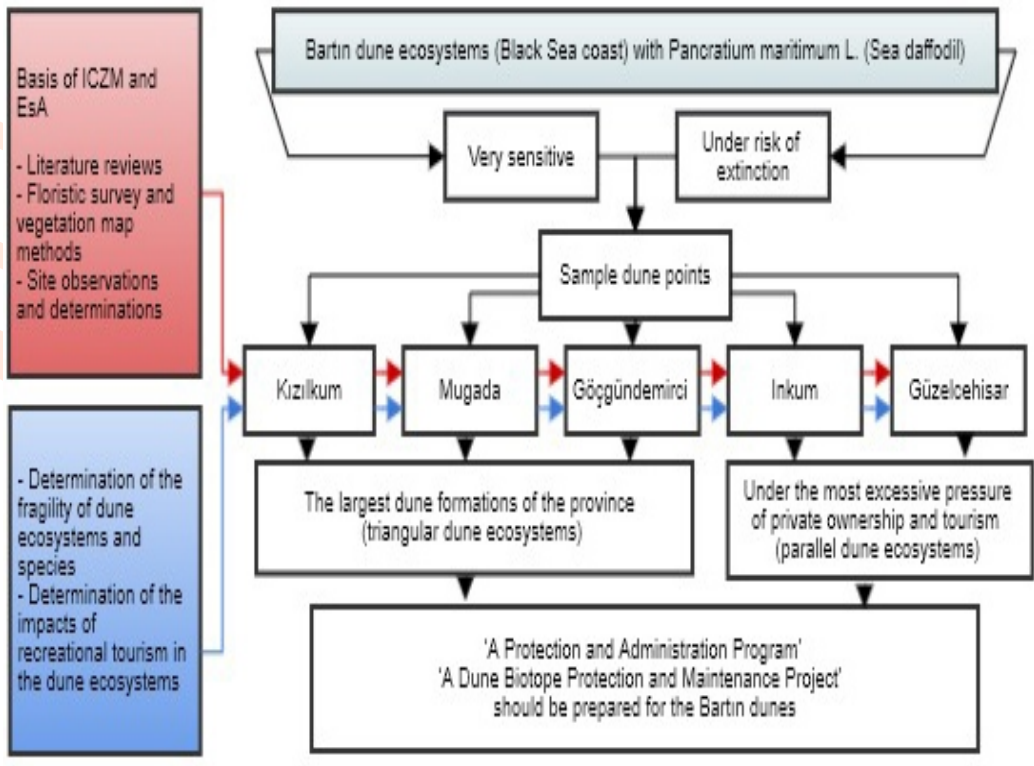

How to cite : Sarı Nayim, Y.: Assessment of sand dune ecosystems with Pancratium maritimum, Bartın, Turkey. J. Environ. Biol., 41, 483-490 (2020). 


\section{Introduction}

Much attention has been given to tropical ecosystems due to their species richness (Whitmore 1984), high standing biomass (Bruenig, 1983; Bargali and Singh, 1997a, b) and greater productivity (Jordan, 1983; Bargali and Singh, 1991, 1995; Bargali et al., 1992) but during last few decades these ecosystems have faced lot of anthropogenic pressures (Jhariya et al., 2014; Baboo et al., 2017).

Dune ecosystems are part of tropical regions, different from other ecosystems and have a more sensitive structure,for this reason. They have been taken under protection with the EU Natura 2000 Network Habitat Directives (Valles et al., 2011). Even though coastal dunes cover small areas on the earth, they contain a wide range of biological diversity. However, coasts have also been affected by the adverse developments that have been experienced in the world over the past 50 years. The pressure of humans on the coastal zones has increased dramatically during this period. The result has been landscape breakdown when the inability to apply proper management policies was coupled with the rapid extinction of many species that are special to dune ecosystems along with the loss of habitat (Carranza et al., 2008).

Dune ecosystems support variation of plant and animal societies. Dunes provide habitat for a wide range of species from plants and mushrooms to invertebrates which have adapted to these special conditions. Orchids, bees and butterflies can completely develop and grow in these habitats (South East Biodiversity Strategy, 2009). Dune ecosystems are special areas for people due to their scenic values since they are located where the seas meet the forests. About one million people travel all around the world every year to visit dunes and coastal areas. These areas enable the visitors the chance to experience clean air, ability for movement as well as the chance to discover the beauties of nature (The Coastal Centre, 2014). Coastal dune is a major tourist attraction and coastal recreation area. Coastal sand dunes in urban areas are affected significantly by the activities of humans (Gold Coast City Council, 2007). The dynamic nature of dune ecosystems should be protected. It should be kept in mind that dunes are sensitive ecosystems and can easily be harmed from human activity.

Beach and front dune section are most affected from dune ecosystems with different characteristics, however, beaches can tolerate heavy recreational uses (Department of Natural Resources, 2013) and front dunes are sensitive to pressure (Queensland Government, 2013). Indeed, this sensitivity is related to the number of people who intervene the natural process and functions of the dune system. People using beaches are not aware of the importance of dunes with regard to the existence of beaches as well as their sensitivity to anthropogenic effects. Human pressure may damage dune vegetation. All dune ecosystems should be considered not only as areas of relaxation, but also as areas that are significant for the ecological system as well as a part of the ecological process (The Coastal Centre, 2014).

The properties of dunes that set them apart from other ecosystems and makes them unique are harsh environmental conditions as well as a potential of rare plant and wildlife potential that have adopted to these conditions. It has been observed that the species living in these rare ecosystems are generally classified as species that are under risks in the floristic lists of the region (The Coastal Centre, 2014). Existing native dunal vegetation provides a seed bank of plants for future generations, thus maintaining the natural biodiversity of the area (Gold Coast City Council, 2007). Dune plants are also important for the formation of dune areas, their development and sustainability. However, rare dunes along with the species that live in these ecosystems are facing a danger of extinction due to excessive and misuse as well as improper developments. Among these, settlement areas (buildings, roads etc.), dune cleaning and organization vehicles, car parks, intense pedestrian and vehicle circulation as well as many other recreational uses along with the dumping of solid wastes, sand delivery, coastal arrangements, breakwaters and of course the invasion of foreign species come first (Gold Coast City Council, 2007; Department of Natural Resources, 2013; The Coastal Centre, 2014).

The recovery period of damaged dunes and dune types can take a long time for dune areas with difficult surrounding conditions. That is why a management plan and follow up policy should be developed to prevent and recover the damages caused by recreational uses of dune ecosystems along with protective activities (The Coastal Centre, 2014). Various laws and programs help in the protection of dune areas abroad (Department of Natural Resources, 2013). Some dune areas have been classified as 'Critical dunes' in developed countries as a result of defining the species, ecological societies and important habitat types that are under threat. Dune areas are designed in accordance with various uses within the framework of international agreements, European Habitat Directives and national laws (Department of Natural Resources, 2013; JNCC, 2014). Whereas it is observed that different methods are tried for dune management at local level. Among these hard protection methods, access management and public awareness come first (South East Biodiversity Strategy, 2009).

The principles of Integrated Coastal Zone Management (ICZM) and Ecosystem Approach (EsA) that were put forth as a result of Agenda 21 and Rio Conference outputs support the protection of natural habitats such as sensitive dune ecosystems. Both approaches aim to share the benefits obtained from natural resources for the benefit of society (Haines-Young et al., 2011). The second item of ICZM Protocol stats that, 'All elements relating to hydrological, geomorphological, climatic, ecological, socioeconomic and cultural systems should be taken into account in an 
integrated manner, so as not to exceed the carrying capacity of the coastal zone and to prevent the negative effects of natural disasters and development'. The $10^{\text {th }}$ item of Biological Diversity Agreement states that, 'The Ecosystem Approach should seek appropriate balance between, and integration of, conservation and use of biological diversity' are expressions that lead the way for this study (European Commission, 2009b; Haines-Young et al., 2011; Secretariat of the Convention for Biological Diversity, 2015).

Black Sea Coasts are host to complex ecosystems that provide a vital refuge for many rare habitats and species (European Commission, 2009a). Pancratium maritimum belongs to Amaryllidaceae family is a rare species of Black Sea dunes. Its habitat is coastal dune areas and dunes and is widely spread in the Mediterranean area, Bulgaria, W. Transcaucasia (Black Sea Coast). It is widely known as sea daffodil, sand lily or sea lily and is a bulbed and perennial plant. Its white and fragrant flowers bloom during the $6^{\text {th }}$ and $10^{\text {th }}$ months (Davis, 1965-1985). According to IUCN (2014), Pancratium maritimum taxa is listed as 'Endangered' and faces extinction due to intensive tourism and recreational use in the limited areas of Bartın dunes. Turkey includes many important species and ecosystems such as Pancratium maritimum and Bartın Dune due to its biogeographic properties.

In view of the above, this study was carried out to examine the actual density and habitat of the Sea daffodil species at Bartın Dune which is under high risk; discussing the effects of increasing touristic and recreational activities at Bartın Dune on Sea daffodils and their natural habitats of dune biotope; developing suggestions for the protection and management of species under national and local threat along with its natural habitat of dunes; and increasing awareness regarding protection of dune ecosystems.

\section{Materials and Methods}

In this study, the dunes of Güzelcehisar and Göçgündemirci, which has an important place in the coastal ecosystems of Bartın province and belong to ${ }^{\text {st }}$ Degree Natural Site category and the dunes of İnkum, Mugada and Kızılkum which are not under protection were examined. The city of Bartın where Kızılkum, Mugada, Güzelcehisar, Inkum and Göçgündemirci dune ecosystems are located in the Western Black Sea Region of Turkey.

Inkum is a touristic settlement area that is closest to the city of Bartın at a distance of only $12 \mathrm{~km}$ and a driving time of $19 \mathrm{~min}$. The settlement that is located to the north of the city center and to the west of the Bartın Port has been established over a coastal region on the banks of cliffs and is $3 \mathrm{~km}$ long (Sarı Nayim, 2017a).

Kızılkum is located $25 \mathrm{~km}$ north-west of the city of Bartın. It is the largest dune with a length of approximately $4 \mathrm{~km}$. Mugada is $20 \mathrm{~km}$ from the city center and covers $1.5 \mathrm{~km}$ long sand dune area. Güzelcehisar is $17 \mathrm{~km}$ from the city center and occupies There is a dune area of approximately $700 \mathrm{~m}$. Göçgündemirci is third important dune of Bartın after Kızılkum and Mugada. The sand dune, which is $22 \mathrm{~km}$ away from Amasra District, is $1 \mathrm{~km}$ long parallel to the shore (Western Black Sea Development Agency, 2019).

In the study, the sea daffodils and Bartın dunes were examined under two headings:

- $\quad$ the fragility of Bartın coastal dune ecosystems and Pancratium maritimum species,

- $\quad$ the impact of tourism activities and recreational uses in the Bartın dune ecosystems.

The data that have been acquired from literature reviews, floristic studies, site observations and determinations have been evaluated on the basis of Integrated Coastal Zone Management (ICZM) Protocol and Ecosystem Approach (EsA) (European Commission, 2009b; Haines-Young, 2011; Secreteriat of the Convention for Biological Diversity, 2015). Vegetation/Floristic survey and vegetation map methods are generally preferred for the management of human effect in coastal recreation areas (Carlson and Godfrey, 1989; Ministry of Environment and Urbanisation, 2010). Field studies were carried out to record the floristic data and habitat information of sea daffodil at Bartın Dune. Distribution of individuals were mapped and rating was carried out according to their densities.

In this scope, the studies were first carried out in the Inkum Dune that is most intensively used area. The study area of the Inkum settlement area was divided into 9 different pieces, thus enabling a more detailed recording of field studies. Flora studies were carried out at 54 different points over the coastal dune area and based on the property of Pancratium maritimum species determined in 41 of the sample points;

- numbers of broodstock and young individuals of Pancratium maritimum were determined,

- areas where only a single specie is dominant or where there is a spreading together with other dune species were marked and their degrees of availability were recorded.

In accordance with the habitat properties of Pancratium maritimum;

- the availability of sea daffodils over high dunes due to the effect of strong winds were recorded, information about whether their spreading areas are surrounded with wooden fences or not was recorded,

- information about whether there is a sign post for 
information and warning was present or not was recorded.

In addition, touristic and recreational threats to the İnkum Dune were determined. Within this scope, the touristic and recreational user capacities during tourism season were examined and data regarding the current number of residences in the region, car park capacity and the number of cars visiting the region during official holidays were recorded (Bartın Municipality, 2014; İnkum Gendarmerie Station Command, 2014). The relationship between user capacity and the density levels of the species was examined and evaluations were carried out regarding their protection against the sensitivity of the species and the ecosystem as well as human effects.

Additionally, at 13 sampling points in Kızılkum, and 6 sample points in Mugada, Güzelcehisar and Göçgündemirci coastal dunes, flora were examined and habitat evaluations were made. Touristic and recreational threats to the Kızılkum, Mugada, Güzelcehisar ve Göçgündemirci dunes were determined.

\section{Results and Discussion}

The presence of coastal dunes in the province of Bartın makes an important contribution to the species and habitat diversity in the province. On the shores, extending parallel to the Black Sea, the elevation increases from the west to the east. In this study, sand dune formations occur in parallel or triangular form in natural covers where dry or irrigated rivers reached the sea. The formation of largest dune of the province was seen on the shores of Kızılkum, Mugada and Göçgündemirci.

Fragility of Kızılkum coastal dune ecosystem and Pancratium maritimum species: Kızılkum coastal dune is the most important and largest dune area of the province. From the sea towards the inland, the beach includes a moving and then a consistent sand dune belt. In the fixed dune belt, there are dune hills which are also found in Mugada. Species of Cakile maritima (Sea rocket) and Pancratium maritimum (Sea daffodil), two of the few special sand dune plants that can cope unfavourable conditions arising from the sea and sand with their special root and stem system, determined in the beach belt. For this, 13 different dune sampling points were examined. It was observed that sea daffodil broodstocks, which tend to spread in the beach belt, had young individuals in their places or destroyed completely. Recreational tourism facilities such as hotels, cafeterias, children's playgrounds, car parks, transportation and new residential areas related to beach use have been found to adversely affect the dune and destroy the dune vegetation. Pressure factors such as excessive grazing and sand intake also contribute to this negative process.

Fragility of Mugada coastal dune ecosystem and Pancratium maritimum species: It is the second largest sand dune after Kızılkum. During the field studies, sand dune flora was examined at 6 samplinf points in Mugada coastal dune. There were 150 broodstock and young sea daffodil individuals at first point. Broodstock plants were distributed individually or in groups. At second point, sea daffodils were spread, majority of which were offspring and their distribution intensified near the sea. At third point, 200 broodstock and offspring were observed. At fourth point, 500 broodstocks and young individuals were observed in the entire dune, however, solid wastes were observed, especially in this region and they adversely affected the distribution of vegetation. At fifth point, there were 300 broodstock sea daffodils and intense offspring in the areas close to the sea. Excess solid waste was observed at this point. At sixth point, there were 200 broodstocks and the presence of dense waste was recorded. In recent years, hard ground, bungalow and recreation area arrangements built by the local government prevented the dune movement and caused great damage to vegetation.

Fragility of Güzelcehisar coastal dune ecosystem and Pancratium maritimum species: A significant part of the Güzelcehisar coastal dune is under private ownership. It was found that these areas have been removed from the common public use status and used as private-run camp, daily recreation area and secondary housing area. Furthermore, the wooden walking platform with steel frame placed on the coastline is thought to have a negative impact on the dune and vegetation on the beach. During the field studies carried out at six different sampling points, 450 Pancratium maritimum broodstocks stuck to the corners of the parcel were observed. Six sampling points included a private residential garden, a cafeteria garden and four natural dune habitats. Field observations once again proved that the sheltering and reproduction of sea daffodil and other dune species in Guzelcehisar were also hindered due to human interventions.

Fragility of İkum coastal dune ecosystem and Pancratium maritimum species: İnkum Dune is one of the sensitive coastal biotopes of the city of Bartın that should be under protection. It is replaced by $200 \mathrm{~m}$ high sea cliffs. It belong to parallel dune class among the main dune types. It lies close to the connecting point of Bartın River and Black Sea and is parallel to a large and shallow cove. Since it is close to Bartın River estuary, a significant amount of sand which has helped to create dunes has been transported to the İnkum Dune for centuries.

The dune is bordered by pedestrian and vehicle and remains busy, especially during summer due to touristic activities. The dune vegetation is under threat and is at the verge of extinction, however, no precautions are being taken. Dune steps have formed because of the wind effect at places far away from any human interaction. Species specific to the dune biotope have been observed more intensely On the areas close to the road and away from the beach entrance. These areas act as a kind of shelter for dune species. The result of field studies and data evaluation show that the taxa classified as 'Endangered' according to IUCN (2014) data is facing extinction. 
On examining the vegetation and habitat information recorded in 9 different maps, it was observed that Pancratium maritimum was absent on $1^{\text {st }}, 7^{\text {th }}, 8^{\text {th }}$ and $9^{\text {th }}$ maps. It was observed that Sea daffodil were spread and these areas had least structuring. 222 broodstocks, 325 young individuals were observed at 14 different spots on $4^{\text {th }}$ map; 170 broodstocks and 152 young individuals were observer at 13 sampling points on $3^{\text {rd }}$ map. This was followed by 6 different spots on $2^{\text {nd }}$ map where 55 broodstocks and 90 young individuals were observed. When the population intensity at the sampling points were examined, the number of broodstock species was higher in the areas surrounded by wooden fences. During field study, sea daffodils on $5^{\text {th }}$ map were away from intensive pedestrian transportation and beach use, and that they had taken refuge at the top of high dunes due to the effect of strong winds.

Fragility of Göçgündemirci coastal dune ecosystem and Pancratium maritimum species: Due to its topography, geomorphological character and Black Sea coastal climate, the area consist important ecosystems and species diversity in terms of nature conservation. At top are the ecosystems of forests and bushes that cover steep slopes of the valley where the village settlement is located. In addition, the narrow and deep river valley in the area is surrounded by rural settlements and agricultural areas.

The dune ecosystem constitutes one of the different landscape spaces in the area. In the floristic studies carried out at 6 different sampling points on the shore of Göçgündemirci, Pancratium maritimum as 'Endangered' were found in abundance as broodstock and young individuals. It was observed that Medicago marina and rare specie Peucedanum obtusifolium along with Cakile maritima, which is one of the front dune plants, spread extensively in the area. In addition, Euphorbia paralias, Eryngium maritimum, Glaucum flavum Crantz. (Yellow horned poppy) individuals were found at certain points. In some dune hills, woody Cionura erecta (L.) Griseb. was found dominant and it was noted that they sheltered he areas between the dune and pedestrian-vehicle routes, especially at places where human activities were intense.

Impact of tourism activities and recreational uses in the Bartın Dune Ecosystems (İnkum, Kızılkum, Mugada, Güzelcehisar and Göçgündemirci) : Inkum is the touristic settlement of the city of Bartın that is under excessive human pressure. One of the most important reasons for this excessive pressure is that the region is close to the city center. Inkum has faced many touristic activities, recreational uses and second residence structuring because of this issue.

According to the municipality records, there are 3500 second residences at the Inkum settlement area. The car parking capacity as determined by the Gendarmerie Station Command was 1750 . The number of cars that visited the İnkum settlement during an official holiday in 2014 was recorded as 63,000 . About $3,00,000$ tourists came to the region during this time (Bartın Municipality, 2014; İnkum Gendarmerie Station Command, 2014). These data put forth that Inkum Dune system is facing a touristic and recreational use pressure resulting from over ecological carrying capacity. The best proof for this is that all dune plants have completely become extinct in the $1^{\text {st }}, 7^{\text {th }}, 8^{\text {th }}$ and $9^{\text {th }}$ maps, which are frequently used areas.

Some of the negative effects that were determined on Pancratium maritimum population and Bartın Dune during field studies are as follows:

- IInkum, Mugada and KızIlkum dunes are currently not protected. Sea daffodils and other important dune species are under threat.

- Güzelcehisar and Göçgündemirci dunes, which are protected within the scope of $1^{\text {st }}$ Degree Natural Site, are under pressure due to unplanned recreational tourism activities and investments.

- $\quad$ Dune ecosystem is under excessive use compared with the past because of human activities that have exceeded its capacity.

Parallel with increasing use, no planning has been done that might decrease the pressure on the dune ecosystem and dune vegetation and the required care and attention are not given.

The fragrant flowers of Pancratium maritimum are collected by local public or visitors.

- The broodstock individuals of species have been removed from their spots by individuals and are mindlessly carried over to other spots.

- Locals who are interested in plant production collect the seeds of the plant freely and in a senseless manner; hence preventing the increase of young individuals.

- The population of species continue to decrease due to increasing human pressure and there is no sufficient protection.

- Smashing and drying are observed due to excessive use of beach.

- Billboards have been put up recently that aim to increase awareness for the protection of sea daffodils. However, there are incorrect or missing information on these billboards.

- The Sea Daffodil Festival' organized at İnkum is celebrated with concerts instead of activities related to preservation of species. 
- $\quad$ Those who use sand dunes leave their wastes behind. It is observed that only human factor is dominant on the dune areas, other species of life are ignored and there is a senseless use of coastal areas. Tractors and scoops are used by the municipality before summer season on the dune areas which adversely affects the texture of dune areas as well as those species living there. Local public and visitors of Bartın dunes do not have sufficient information about dune ecosystems and dune vegetation. Required information is not given by the local administrations and non-governmental organizations regarding environmental protection, and most importantly, there is no description about the measures that should be taken to ensure the continuity of Bartın dune ecosystems, as well as the species that are facing threats of extinction in the 1/100000 Environmental Plan as well as the $1 / 5000-1 / 1000$ Municipality Zoning Plans (Bartın Municipality, 1980; 1988).

Suggestions : Keeping in view the above, the measures for protecting Pancratium maritimum and the biotopes at Bartın dune ecosystems have been listed below:

- $\quad$ According to the Resolution No. 740 dated 12/3/2008 of the Supreme Council for the Protection of Cultural and Natural Heritage affiliated to Ministry of Cultural and Tourism (2007), natural protected areas are described as: 'The places that are of universal value in terms of scientific preservation should be protected for public interest due to their rare and interesting features and beauties, and should be protected. These principles should be followed for the health of dunes in Güzelcehisar and Göçgündemirci bays within the scope of $1^{\text {st }}$ Degree Natural Site in the area.

- Kı K Kılkum, Mugada, Güzelcehisar, İnkum, Göçgündemirci dunes is included in the '2110 Embryonic Shifting Dunes' scope according to the EU Natura 2000 Habitat types of the Black Sea Region as one of the sub-habitats of 'Coastal Sand Dunes and Inland Dunes' (EIONET, 2008; Sarı Nayim, 2017a). Pancratium maritimum is one of the most characteristic species if this habitat and should be preserved.

- $\quad$ The biotope mapping studies carried out by Sarı Nayim and Nayim (2016), Sarı Nayim (2017a), Sarı Nayim (2017b), Nayim and Sarı Nayim (2018) researches have classified the Kızılkum, Mugada, Güzelcehisar, İnkum and Göçgündemirci dunes as sensitive biotopes. According to the floristic studies carried out by Bollukçu (2007) and Sarı Nayim (2017a), Pancratium maritimum is among the rare species of Black Sea dunes spreading over the Kızılkum, Mugada, Güzelcehisar, İnkum, Göçgündemirci dunes. Accordingly, critical dunes and there species should be legally taken under protected areas. Cliffs, rivers, pseudomaquis, forest and agriculture biotopes, near the dune areas should also be taken under protection.

- 'A Protection and Administration Program' should be prepared for the Bartın dunes.

- Actual dune vegetation data should be taken into account in terms of coastal management and plans.

- A 'Dune Biotope Protection and Maintenance Project' should be prepared for the Bartın dunes and proper uses should be designed in accordance with sensitivity level. Rejuvenation of these areas will take a long time and so pedestrian transportation network to the area should be redesigned immediately. Wooden elevated boardwalks and special viewing platforms should be preferred in these areas.

Projects and programs that will be prepared should be shared with the local and central administrations via activities such as meetings, panels etc.

- The ecologic carrying capacity of Bartın coastal settlements and dune habitats should be determined immediately.

Damaged dunes and dune plants should be surrounded by wooden fences and enclosures. The opportunities for the growth of sea daffodils in their natural habitat should be researched with the cooperation of the university and local administration. Administrators should support studies conducted on dune ecosystems. A workshop entitled 'The Importance of Bartın Dune Areas' should be organized with the support of the university and the participation of expert academics will increase the awareness to this issue.

- $\quad$ Flattening and cleaning vehicles that damage the root and rhizomes if dune vegetation should not be forbidden. Private land owners should refrain from activities that will damage dune vegetation and dunes.

- $\quad$ Sensitivity of dunes should be explained to local people and awareness for the preservation of nature should be increased.

- Informative brochures, CDs and guide books should be distributed to the visitors who come from other regions. Visitors should respect the dune vegetation and sensitive dunes.

- $\quad$ English and Turkish billboards for the protection of dunes and dune species should be more widespread. 
- $\quad$ Larger audiences should be reached by using various means of communication such as local television, radio, magazines and newspapers and texts as well as visual materials to increase awareness should be prepared.

- $\quad$ Trekking activities made at the dunes as well as photography and natural tourism activities should be used to inform people about the importance of dunes.

- A photography exhibition of Bartın dunes and the species of this region will contribute to the protection of nature.

- $\quad$ Collective activities such as collection of wastes and removal of foreign species from the area should be organized with the participation of local people will increase the interest of youngsters, especially cheldren towards the dune ecosystem.

- $\quad$ The Natural Resources Protection Commission that will be set up by the Bartın Government should monitor the Bartın dunes at regular intervals and should manage these areas.

In the research area, the dune beaches should be designed in accordance with dune habitats in the moving and fixed dune section and the daily activities within the scope of recreation areas proposed in the conservation development plans.

The final stage is important for the sustainability of the dune ecosystems. The monitoring and management of the ecosystem, determination of negative issues beforehand will be the key for taking necessary precautions and interventions. The government, central and local administrative units, environmental groups, academics, Natural Resources Protection Commission and the society should work in cooperation with the principle of 'for the sake of our coasts we must care for the dunes' as stated in Queensland Government (2013).

\section{Acknowledgments}

This research was supported by The Scientific Research Projects Commission Directorate of Bartın University (Project no: 2013.2.112; Project no: 2016.FEN.012 and Project no: 2017.FEN.A.018). Autjoe like to thank the Scientific Research Projects Commission of Bartın University for the partial financial support.

\section{References}

Baboo, B., R. Sagar, S.S. Bargali and H. Verma: Tree species composition, regeneration and diversity within the protected area of Indian dry tropical forest. Trop. Ecol., 58, 409-423 (2017).

Bargali, S.S. and R.P. Singh: Pinus patula plantations in Kumaun Himalaya. I. Dry matter dynamics. J. Trop. For. Sci., 9, 526-535 (1997a).
Bargali, S.S. and R.P. Singh: Pinus patula plantations in Kumaun Himalaya II. Nutrient dynamics. J. Trop. For. Sci., 10, 101-104 (1997b).

Bargali, S.S. and S.P. Singh: Aspect of productivity and nutrient cycling in an 8-year-old Eucalyptus plantation in a moist plain area adjacent to Central Himalaya, India. Cana. J. For. Res., 21, 1365-1372 (1991).

Bargali, S.S. and S.P. Singh: Dry matter dynamics, storage and flux of nutrients in an aged eucalypt plantation in Central Himalaya. Oecologia Montana, 4, 9-14 (1995).

Bargali, S.S., S.P. Singh and R.P. Singh: Structure and function of an age series of eucalypt plantations in Central Himalaya, I. Dry matter dynamics. Ann. Bot., 69, 405-411 (1992).

Bartın Municipality: Map of the master plan of the İnkumu settlement and its surroundings, $1 / 5000$, Bartın Municipality Directorate of Reconstruction Works, Bartın. Bartın Belediyesi: İnumu yerleşimi ve yakın çevresine ait nazım imar planı paftaları, 1/5000, Bartın Belediyesi İmar İşleri Müdürlüğü (1980).

Bartın Municipality: Map of the master plan of the Inkumu settlement and its surroundings, 1/1000, İnkumu yerleşimi ve yakın çevresine ait imar planı paftaları, 1/1000, IIller Bankası, Ankara (1988).

Bartın Municipality: Number of built housing in İnkumu, Bartın Municipality Directorate of Reconstruction Works, Bartın. Bartın Belediyesi: İnkumu yerleşik konut sayısı, Bartın Belediyesi İmar İşeri Müdürlüğü, Bartın (2014).

Bollukçu, P.: Investigation of the Effects of Tourism on Coastal Ecosystem in Coastal Areas in Bartın Case. $3^{\text {rd }}$ National Congress of the Chamber of Landscape Architects, 22-25.11.2007, Kıyısal Alanlarda Turizmin Kumul Ekosistemi Üzerine Etkilerinin Bartın Örneğinde İrdelenmesi, Peyzaj Mimarları Odası 3. Ulusal Kongresi, 22-25.11.2007, Antalya, Türkiye (2007).

Bruenig, E.F.: Vegetation structure and growth. In: Tropical Rainforest Ecosystems: Structure and Function (Ed.: F.B. Golley). Elsevier Scientific Publishing, Amsterdam, pp. 44-75 (1983).

Carlson, L. H. and P.J. Godfrey: Human impact management in a coastal recreation and natural area. Biol. Conserv., 49, (1989).

Carranza, M.L., A.T.R. Acosta, A. Stanisci, G. Pirone and G. Ciaschetti: Ecosystem classification for EU habitat distribution assessment in sandy coastal environments: An application in Central Italy. Environ. Monit. Assess., 140, 99-107 (2008).

Davis, P.H.: Flora of Turkey and the East Aegean Islands. Vol. 1-10, Edinburg University Press, Great Britain (1965-1985).

Department of Natural Resources: Coastal Dunes. Michigan's Official Website www.michigan.gov/dnr/ (28.06.2013).

EIONET: Blacksea Region Reference List, Natura 2000 Habitat Directive Annex I-II, ETC/BD, France, http://biodiversity.eionet.europa.eu/ activities/Natura_2000 (2008).

European Commission: Natura 2000 in the Black Sea Region, European Commission, Luxembourg, ISBN 978-92-79-11585-1, p. 12 www.ec.europa.eu/environment/nature (2009a).

European Commission: Protocol on Integrated Coastal Zone Management in the Mediterranean, Official Journal of the European Union, 19-28. http://ec.europa.eu/environment/iczm/ barcelona.htm (2009b).

Gold Coast Planning: Management of Coastal Dune Areas. Planning Scheme Policies, Policy 15, Gold Coast City Council, p. 33 www.goldcoast, gld.gov.au (2007).

Haines-Young, R. and M. Potschin: Integrated Coastal Zone Management and the Ecosystem Approach. Deliverable D2.1, 
PEGASO Grant Agreement No:244170. CEM Working Paper No:7, p.17 (2011).

IUCN: The IUCN Red List of Threatened Species, International Union for Conservation of Nature and Natural Resources. www.iucnredlist. org (2014).

Inkum Gendarmerie Station Command: Vehicle Sign Reading System Data, Bartın. İnkum Jandarma Komutanlığı: Araç Tabela Okuma Sistemi Verileri, Bartın (2014).

Jhariya, M.K., S.S. Bargali, S.L. Swamy, B. Kittur, K. Bargali and G.V. Pawar: Impact of forest fire on biomass and carbon storage pattern of tropical deciduous forests in Bhoramdeo Wildlife Sanctuary, Chhattisgarh. Int. J. Ecol. Environ. Sci., 40, 57-74 (2014).

JNCC: Terrestrial Habitats, UK Habitat Classification. Joint Nature Conservation Council, UK. www.jncc. defra.gov.uk (2014)

Jordan, C.F.: Productivity of tropical rainforest ecosystems and the implications for their use as future wood and energy sources. Pages 117-136, In: Tropical Rain Forest Ecosystems: Structure and Function (Ed.: F.B. Golley). Elsevier Scientific Publishing, Amsterdam (1983).

Ministry of Cultural and Tourism: Resolution No. 740 date 03.12.2008, High Council of Cultural and Natural Assets Protection, Ankara. Kültür ve Turizm Bakanlığı: 12/3/2008 tarih 740 sayılı İlke Kararı, Kültür ve Tabiat Varılılarını Koruma Yüksek Kurulu, Ankara (2008).

Ministry of Environment and Forestry: Zonguldak-Bartın-Karabük Planning Region Environmental Plan and Report, 1/100000, Jeotek Ltd. ve UTTA Planning Ltd. business partnership, Ankara. Çevre ve Orman Bakanlığı. Zonguldak-Bartın-Karabük Planlama Bölgesi Çevre Düzeni Planı ve Raporu, 1/100000, Jeotek Ltd. ve UTTA Planlama Ltd. iş ortaklığı, Ankara, 978-975-585-881-4. (2009).

Ministry of Environment and Urbanisation: Belek, Patara Special Environmental Protection Area of Sand Lily (Pancratium maritimum) Protection and Monitoring Project. General Directorate of Protection of Natural Assets. Çevre ve Şehircilik Bakanlığı: Belek-Patara Özel Çevre Koruma Bölgesi Kum Zambağı (Pancratium maritimum) Koruma ve İzleme Projesi. Tabiat Varıklarını Koruma Genel Müdürlüğü, Ankara www.csb.gov.tr (2010).

Nayim, B.N. and Y. Sarı Nayim: A methodological approach to spatial analysis in determining protected areas, The Case of Amasra (Bartın). Alanya, Turkey. Koruma Alanlarının Belirlenmesinde Mekansal Analizlere İlişkin Metodolojik Bir Yaklaşım, Amasra Örneği (Bartın). ENAR 2018 Uluslararası Mühendislik ve Mimarlık Kongresi,, 14-16 Kasım 2018, Alanya, Turkey (2018).

Queensland Government: Coastal Dunes/Beach Conservation, Department of Environment and Heritage Protection. www.ehp. gld.gov.au/coastal/ecology/beaches-dunes/coastal-dunes.html (28.06.2013).

Sarı Nayim, Y. and B.N. Nayim: Identification of important ecosystems in terms of biodiversity in Güzelcehisar (Bartın) coastal landscape (Western Black Sea, Turkey). 1. International Black Sea Congress on Environmental Sciences (IBCESS), Giresun, Turkey (2016).

Sarı Nayim, Y.: Mapping of biotopes between Amasra and İnkum (Bartın), Western Black Sea Regon of Turkey. J. Environ. Biol., 38, 1033-1042 (2017a).

Sarı Nayim, Y.: Conservation of local fruit species belonging to Bartın Forest Habitats, Turkey. In: Current Trends in Science and Landscape Management (Eds.: R. Efe, M. Zencirkıran, J.A. Wendt, Z. Tumsavas, H. Ünal and B. Borisova). Chapter Fourtyeight, ST. Kliment Ohridski University Press, ISBN: 978-954-074338-7, Sofia, Bulgaria, pp. 577-586 (2017b).

The Coastal Centre: Beach Conservation, Learning about Beach and Dune Ecosystems, The Coastal Centre, The Lake Huron Centre for Coastal Conservation, Canada. www.lakehuron.on.ca (2014).

Secreteriat of the Convention for Biological Diversity: Ecosystem Approach/Principles, Convention on Biological Diversity. www.cbd.int/ecosystem/principles.shtml (2015).

South East Biodiversity Strategy: Coastal Sand Dunes, South East Biodiversity Strategy, UK. www.strategy.sebiodiversity.org.uk/ pages/coastal-sand-dunes.html (28.06.2013) (2009).

Valles, S.M., J.B.G. Fernandez and C.M. Dellafiore: Dune vulnerability in relation to tourism pressure in Central Gulf of Cadiz (SW Spain), a case study. J. Coast. Res, 27, 243-251 (2011).

Western Black Sea Development Agency 2019. Deniz turizmi. Batı Karadeniz Kalkınma Ajansı. Sea Tourism, Bartın Investment Support Office, http://bartınyatırım.com (2019).

Whitmore, T.C.: Tropical Rain Forest of Far East. $2^{\text {nd }}$ Edn., Claredon Press, London (1984). 